\title{
Monitoring and Evaluation on Effective Delivery of Social Studies for Improved Academic Performance
}

\author{
Chukwu, Chinyere Loveth ${ }^{1}$, Mezieobi, Dan I. ${ }^{1}$, Uguwanyi, Benedict Ejiofor ${ }^{1}$ \& Okpoebo, Casmir Chukwudi ${ }^{1}$ \\ ${ }^{1}$ Department of Social Science Education, University of Nigeria, Nsukka, Nigeria \\ Correspondence: Daniel Mezieobi, Department of Social Science Education, University of Nigeria, Nsukka, Nigeria
}

Received: November 4, 2018 Accepted: January 21, 2019 Online Published: February 20, 2019

doi:10.5539/res.v11n1p175

URL: https://doi.org/10.5539/res.v11n1p175

\begin{abstract}
Monitoring and evaluation is very crucial in attaining targeted goals, especially in social studies. Social studies teacher mode of service delivery rub-off on the level of academic performance of students. It is very imperative that monitoring and evaluation mechanism be put in place to check how social studies lecturers in institutions of higher learning execute their lecture. In primary and secondary levels of education, the Ministry of education, from time to time send inspectors to schools to supervise the teaching and learning processes going on in schools. School heads are also mandated to supervise teaching and learning processes in their schools, this mechanism goes a long way to checkmate teachers' excesses but this is lacking in institutions of higher learning, and appears to be responsible for the lackadaisical attitude to work by some lecturers. Such attitudes include absent from lecture, late coming to lecture among others. This paper therefore looked at the importance of monitoring and evaluation of teaching processes of social studies in higher institutions of learning, uses of monitoring and evaluation, among others and conclude that internal monitoring and evaluation team be established in higher institutions, to ensure adequate monitoring and evaluation of teaching and learning of social studies in institutions of higher learning for effective implementation of social studies contents among others.
\end{abstract}

Keywords: academic performance, effective delivery, higher institutions, monitoring and evaluation, social studies 1. Introduction

Education is considered as an investment in human beings in terms of development of human resources, skills, motivation, knowledge and critical thinking. Higher education is a major driver of economic competitiveness in an increasingly knowledge driven global economy. The imperative for countries to improve employment skills calls for quality teaching within educational institutions (OECD, 2017). Monitoring and Evaluation helps to build an educational programme, assess its achievements and improve upon its effectiveness (Disha, 2017). An effective monitoring and evaluation is strategic to determining how well a training programme can meet its objectives and serves the target audience. Hobson, Mayne and Hamilton, (2013) argued that monitoring and evaluation is a way of systematically measuring and tracking programme activities and results. It becomes imperative that monitoring and evaluation of what goes on in the lecture room between lecturers and students be given adequate audience.

It is pertinent to observe that in basic and post basic education in Nigeria, there is inbuilt supervision of teaching and learning of social studies known as internal and external evaluation. Internal evaluation which is also called institution self-evaluation is a continuous internal evaluation carried out by the school management team and school management committee, using national school self-evaluation form to ascertain how well the institution is achieving set objectives (Federal Ministry of Education [FME] and Federal Inspectorate Service [FIS], 2010). While External evaluation is a form of evaluation carried out in institutions by a team of accredited evaluators selected from National Education Quality Assurance Body and State Education Quality Assurance bodies nationwide (FME and FIS, 2010). Institutional self-evaluation helps to constantly and internally improve the quality of teaching and learning. The internal evaluation is being conducted on basic education levels by the School Based Management Committee (SBMC) Members, Head Teachers, Assistant Head Teacher and Heads of Department (where available) and Experienced Teachers, while in post-basic education, it is carried out by the Governing Board, Principal, Vice Principal(s), Heads of Departments and Experienced Teachers. They go round from time-to-time to monitor how teaching and learning is going on in the classrooms. This activity is a continuous process which takes place frequently in the school to support teaching and learning processes (Chukwu, 2015).

The external evaluation in basic and post-basic educational levels are being conducted by Ministry of Education Officials usually called supervisors or inspectors who go to schools to monitor how teaching and learning are managed. They visit 
schools at least once in a session. In higher institutions of learning there is no internal monitoring and evaluation by the institutional authorities of what happens in lectures rooms during teaching and learning processes except external evaluation which is being conducted by National University Commission (NUC) in higher institutions. It is expected that every higher institution should experience external evaluation at least once in five years (FME and FIS, 2010). During this evaluation, the monitoring team do not usually have the opportunity of monitoring the process of teaching and learning of social studies in the lecture rooms. Sequel to the discussion above, it can be deduced that monitoring and evaluation of an institution once in five years will hamper quick response to teaching and learning challenges which requires urgent attentions to achieve goals. According to Harvey and Struzziere (2008) the outcome of effective internal monitoring and evaluation include skill maintenance, skill improvement and expansion, professional development, reduced stress and enhanced accountability. Quality teaching is an influential factor on learning outcomes. Considering the spate of corruption, moral decadence and other vices (such as sorting, sexual harassment, prostitution, drug abuse etc.) which have engulfed higher institution communities, it becomes imperative to monitor and evaluate how teaching and learning of social studies is being implemented. Only external monitoring and evaluation of teaching and learning process might however result to delayed attention to challenges impeding effective teaching and learning of social studies including learning outcomes. Hence, these may become counter-productive to developing the expected values and morals in students' and encourage corrupt practices in higher institution. According to Myers (2017),

"Social studies aim to produce a responsible individual who will be
able to cope with change, capable to make reasonable decisions,
an intelligent consumer and controller of science and technology,
able to live with and appreciate human diversity, support and
defend human dignity. Such a person should be able to settle
differences honourably, avoid the use of violence, be conscious of, and
active in the stewardship of our planet, and have the skills necessary
to maintain a functional economic system and democratic government",
(pg. 290)

This implies that social studies is expected to produce students who are morally disciplined: who are honest, trustworthy, dedicated and committed to duty, who appreciate hard work, diligence and dignity as against those who delight in armed robbery, prostitution, cultism, kidnapping and rape among others.

Monitoring teaching and learning process is an ongoing tracking and assessment of training programme implementation and performance, usually recording key inputs, activities and outputs on a regular basis, while programme evaluation is a periodic, systematic and in-depth assessment of a training programme whether it has achieved its objectives and whether unintended outcomes have also occurred (Goyal, Pittman and Workman, 2010). Food and Agriculture Organization of the United Nations (FAO) (2017) also believed that Monitoring and Evaluation (M\&E) is a continuous management function to assess if progress is made in achieving expected results, to identify bottlenecks in implementation and to highlight whether there are any unintended effects (positive or negative) from an investment plan, programme or project and its activities. Monitoring and evaluation of teaching and learning of social studies therefore means the process of following-up teaching and learning of social studies contents, considering attitude of lecturers/teachers during teaching, teaching methodologies used, kind of activities applied in teaching and the application of assessment intermittently to ascertain the extent at which set objectives are achieved.

Education Innovation Fund, University of Oxford (2014) observed that monitoring is the collection and analysis of information as it relates to a project or programme while the project/programme is ongoing, while evaluation is a periodic, retrospective assessment of an organisation, project or programme that might be carried out internally or by external independent evaluators. All these definitions of monitoring and evaluation are reflecting on the importance of monitoring and evaluation in any programme. Mwagi, Nyang'wara and Kulet, (2015) concludes that monitoring and evaluation process is a necessary tool that is pertinent in ensuring that main objectives and goals of social studies are realized. It is therefore evident that, education planners and managers (such as Deans, Head of Departments, Unit Co-ordinators and Directors of Schools) who are also programme managers, conduct monitoring and evaluation from time-to-time in their various schedules to ensure that lecturers are delivering their lectures effectively and ensure that they are achieving what is expected to achieve.

Health Mandatory Policy Directive (HMPD) (2005) submitted that carefully monitoring and evaluation of a programme by appropriate team, will help its ongoing development at all levels of education. Monitoring and evaluation of teaching and learning of social studies activities and outcomes will enable teams to reflect on what works and what does not and allows for continuous improvements to be made that will benefit both learner and the teacher. A result oriented monitoring and evaluation, requires, an established strong monitoring and evaluation team whose members are knowledgeable and can assess relevance, practicability and levels of monitoring indicators of a training programme and 
apply best practices in implementing them. In a training programme such as social studies, there is need to decide on the minimum amount of data required to be collected to effectively monitor and evaluate the implementation of social studies courses in the lecture room. The data derived from monitoring and evaluation are strategically important for ongoing improvement and optimization of social studies contents. If monitoring and evaluation of social studies teaching and learning process is properly used, it can become a powerful tool for effective improved lecture delivery and students achievement.

\section{Uses of Monitoring and Evaluation in Teaching and Learning Process in Social Studies}

Monitoring and evaluation in the process of teaching and learning of Social Studies can be used as: 1) Management Tool: Monitoring and evaluation inputs and outputs can help determine whether social studies contents are reaching their target audiences, or whether issues related to content, programme scope, defined coverage areas or target audiences area adhered to and effectively implemented. It also helps in formulation of new plans of action by highlighting what has or has not been accomplished; 2) Accountability to beneficiaries: Information obtained from monitoring and evaluation provides feedback to the institution authorities concerning students opinion on how course contents are taught, scope of courses covered and even the effectiveness of the methodologies being used during teaching and learning; 3) Advocacy: Monitoring and evaluation provides credible information about progress, problems and potentials of teaching and learning of social studies contents. The information gathered will enable the authorities to advocate greater commitment, dedication and support both financial and material for improved lecture delivery; 4) Reporting Requirements: the report of monitoring and evaluation may be required during external evaluation as it would provide area of focus for external evaluators (Goyal, Pittman and Workman, 2010). Having good monitoring and evaluation system in place will provide university authorities with ready access to the basic data they would need to work with for improvement and maintenance and also share with external evaluators.

\subsection{Benefits of Monitoring and Evaluation}

A lot of benefits are derived from monitoring and evaluation. Goyal, Pittman and Workman (2010) identified the following as benefits of monitoring and evaluation: 1) Learning: programme monitoring and evaluation are very important tools for finding out whether the training is really adding to the change we would like to see in the student. When training programme implementation is closely monitored and evaluated, it becomes feasible to understand how the programme works and systematically ascertain what is working or not. Monitoring and evaluation stimulate a continuous-reflection-action cycle which results to programmatic organizational learning. 2) Strengthening: When we understand the contributions made by the training programmes, the educational planners and mangers can make reliable decisions about the steps needed to strengthen them. If evaluation results show that students gained valuable skills in effective teaching and learning, lecturers can feel confident in continuing their activities in that area. By sharing evaluation results within the institution, we can encourage collective ownership of programme outcomes, encouraging every member to strengthen his/her role within the programme. 3) Persuading: It is necessary to share the outcomes that are realized from the training programmes with other lecturers. This is because we have many audience we wish to convince of the value of quality teaching and learning that is going on, from the students in the lecture room to lecturers and unit coordinators, Head of Departments, Deans and Principal Officers of the institution. Evaluation can increase the confidence in teaching and learning of social studies and provide good evidence to support the claim that we are really making a difference in achieving educational objectives.

Also, HMPD (2005) identified the following as the importance of monitoring and evaluation of (social studies teaching and learning process) training program: (a) To provide accountability: it makes lecturers to be accountable for the performance of their students. (b) Tracking of program implementation: this provides information of the activities undertaken in the lecture rooms during teaching and learning. (c) Improving programme: this provides information on identified improvements that can be made to particular aspect of lecture presentation that requires improvement. (d) Showing whether the program is meeting its objectives: this looks at whether teaching and learning is meeting it aims and objectives. (e) Documenting good practice to provide a model for workforce development: this will provide information on best practices in teaching and learning of social studies which can be disseminated as model for workforce development in the education sector.

Importance of Monitoring and Evaluation of teaching and learning process in social studies in institutions of higher learning cannot be over emphasized. Hence the importance also include, to ensure cordial lecturer students' relationship and students students' relationship, accountability, dedication and commitment to duty, conducive learning environment, to checkmate the use of abusive and derogatory language on students, poor attitude to work, the issue of students intimidation, sexual harassment, 'sorting' and examination malpractices.

It is of vital note that effectively accomplished teaching and learning of social studies, brings about not only high academic performance and positive change in students behaviour but will go a long way to stem the various vices that 
have enslaved academic community in the higher institution campuses in recent time.

\subsection{Factors Affecting Monitoring and Evaluation of Implementation of Teaching and Learning of Social Studies}

There is no gainsaying that every programme has its challenges. When a change is introduced, in its early stages, teachers are very likely to have self-concerns. Different factors combine to influence implementation of social studies in the lecture room. The following has been identified as factors affecting monitoring and evaluation of teaching and learning of social studies:

The University Authorities: The support of central administration of the university is strategic for effective change in social studies implementation activities to take place. Many teachers have tough time in being dedicated to teaching and learning of social studies unless administrative support is available. Arnott (2014) said that it is in those schools where administrators are actively involved in change, and support the innovation in a visible and feasible way, that real change takes place. According to Arnott (2014) notable differences in level of implementation have been seen in situations where assistance and support is received from supervisory personnel and consultants.

Quality and Practicality of Innovative Methodology: Teachers would expect materials and programmes which have been prepared with real lecture room situations in mind be made available for effective teaching and learning. They would require professional development programmes which would provide defined, tangible and practical ideas that directly relate to the day to day activities of lecturers. When these are not available, it becomes a challenge. Teachers' professional development initiatives should target change in teacher beliefs, attitudes and perceptions should precede changes in teacher behaviours and practices in the lecture room (Arnott, 2014).

Clarity: Clarity about goals and means pertaining to what is expected of lecturers in handling teaching and learning processes can be a lasting problem. Problems related to clarity can include such things as ambiguous goals or not clearly implementation strategies. If the aims and objectives of monitoring and evaluation including monitoring indicators are not stated clearly to the lecturers, the unclear nature may become a problem as implementation of social studies progresses.

Need: Various innovations are attempted without thinking whether or not they address what is seen as priority needs of students. School authorities usually have programmes full of high priority initiatives. Any initiative introduced should address the need area of the students. It should be an innovation that will improve students learning and achievement.

Complexity: This entails complications which might arise as a result of teachers trying to adopt change. Any change should be looked at in terms of possible use of new or revised materials, the use of new teaching approaches and the alteration of teacher beliefs can bring about complications. Complexity can be a challenge if schools authorities implement innovations that are above the ability of lecturers. New innovations or approaches should appeal to the teachers' professionalism. As a result, professional development programme is imperative to fill the gaps.

Staff Development and Participation: The root of all educational change depends on learning of new ways of thinking and doing things (Arnott, 2014). Therefore, staff development is a critical factor to reorientate teachers to the expected line of thinking, attitude and behavour towards effective teaching and learning of social studies

\subsection{Effect of Absence of Monitoring and Evaluation on Teaching and Learning Processes of Social studies in Higher Institutions}

The absence of monitoring what transpires between lecturers and students in the lecture room can result to the following: (a) poor attitude to work: some lecturers who are not committed to their work, may tend to go for lectures at their own convenience. Such lecturers will often absent themselves from lecture until when it is a few weeks to the examination, then, they will fix lectures even at odd hours; (b) poor students performance: students are likely to perform poorly when the social studies content are not properly or not taught at all; (c) sexual harassment: this is a situation whereby some lecturers exchange unmerited grade with sex; (d) 'sorting': it is a process by which students pay in cash or kind to be awarded unmerited marks by lecturers after examination or test (Chukwu and Taiwo, 2016); (e) use of derogatory and abusive language on students; (f) intimidation: students who are committed and dedicated to their academic work are compelled to sort and in order to further intimidate students, such lecturers sets examination questions out of course contents (Chukwu and Taiwo, 2016); (g) churning out of 'half baked' graduates: this is a situation where students who did not properly go through the course contents to acquire the expected knowledge and skills are graduated and as a result could not defend their certificate; (h) rampant vices in the society such as armed robbery, kidnapping, prostitution, ritual killing, insurgency and militancy: this category of 'half baked' graduates are usually associated with these types of vices; when education has failed them and the certificate has rendered them perpetually unemployed, some of them resort to vices.

The effect of not monitoring teaching and learning of social studies in higher institutions, can metamorphose into other institutional vices such as rape, prostitution, examination malpractice, cultism and drug abuse. The multiplier effect of these vices will not only affect the institution community but also the society at large. Hence the saying that goes thus, if 
you did not plan to succeed, you automatically plan to fail. And also the adage that says if you say education is expensive, try ignorance.

\section{Key Components of Monitoring and Evaluation of Teaching Social Studies}

When developing a monitoring and evaluation plan, the following key components must be involved. They are inputs, processes, outputs, outcomes and impact.

Inputs: Inputs are the set of resources mapped out for a programme. These include human and financial resources, physical facilities, equipment and operational policies that enable services to be implemented.

Process: Process entails the set of activities in which programme inputs are utilized in pursuit of the results from the programme. It also refers to various activities that are implemented to achieve the objectives of the projects.

Outputs: Outputs are the results obtained from the programme level by executing activities using resources. Outputs could be staff performing better as a result of being supervised or students performing better due to improved methodology.

Outcome: Outcome is the set of results expected to occur at the teaching and learning process due to supervision activities and generation of supervision outputs. The intermediate effects are often behavioral and result directly from teaching and learning outputs. They may be necessary to achieve a desired impact. Outcomes may be divided into two components:

Intermediate outcomes and long-term outcomes. Immediate outcomes: are set of results at the teaching and learning level that are closely and clearly linked to the supervision activities. Long-term outcomes: refer to set of results at the teaching and learning level that are long- term in nature and are produced through action of immediate outcomes.

These components can be further analysed for better understanding as presented in Table 1 (using leadership for the analogy).

Table 1. Example of M \& E components with analogy

\begin{tabular}{l|l|l}
\hline $\begin{array}{l}\text { M \& E } \\
\text { Components }\end{array}$ & with & Leadership Analogy \\
\hline Inputs & & Facilitators (Lecturer), marker, flipchart sheets, flipchart board and projector. \\
\hline Processes & The act of facilitation or Lecturing. \\
\hline Outputs & Trained student on leadership skills. \\
\hline Outcomes & $\begin{array}{l}\text { Effective use of leadership skills in the society. } \\
\text { Impact }\end{array}$ & $\begin{array}{l}\text { Improve academic performance of students, } \\
\text { conducive teaching and learning environment. }\end{array}$ \\
\hline
\end{tabular}

These components are guide to monitoring and evaluation.

\subsection{Indicators for Monitoring and Evaluation}

In conducting monitoring and evaluation of teaching and learning social studies, it is pertinent to identify the indicators that will guide the exercise. Indicators are variables that measure the different aspects of a given programme (teaching and learning processes of social studies) such as inputs, process, outputs and outcomes (https//www.unscn.org, 2017). An indicator must be selected to provide evidence that defines the extent to which project interventions are successful in achieving the set objectives.

\subsection{Criteria for Selection of Indicators}

https//www.unscn.org (2017), identified the following criteria for selecting indicators for monitoring and evaluation of teaching and learning social studies: Validity: this ensures that monitoring and evaluation of teaching and learning of social studies, measures what it is intended to; Sensitivity: its changes reflect desired changes; Reliable: It produces the same results when repeated; Uni-dimensional: it measures only one phenomenon; Operational: it is measurable; Objective: 
it is not subject to measurer's biases; Practical: its data collection is reasonably feasible; Comparability: it can compared from time to time or place to place.

\section{Steps Involved in Monitoring and Evaluation (M\&E)}

Step by step guide involved in monitoring and evaluation are identified by Education Innovation Fund University of Oxford (2014) as follows:

\section{Step 1: Why Conduct M\&E?}

The first step is to identify the reason for conducting M\&E of teaching and learning processes of social studies in higher institutions and the benefits it can offer. Doing M\&E can help assess what transpires between lecturers and students in the lecture room and can provide vital intelligence about how the lecturer demonstrate effectiveness in realizing the objectives and impacts on students' lives;

Step 2: Agree on some guiding principles

At this stage it is very vital to develop guiding principles to ensure that the M\&E of social studies teaching and learning in higher institutions is relevant, timely and credible. Some examples might include, making sure the M\&E information collected is focused and realizable.

Step 3: Decide which programme you need to monitor

It is important to decide and prioritise the programmes you would want to monitor. This is because it may be impossible to have the resources needed to monitor all your interventions at the same time. So you will need to decide which programmes you would want to assess; over what period of time; and whether it is an on-going activity which requires monitoring or a completed activity which requires evaluation.

Step 4: Decide on who to include in the various stages of your M\&E

To ensure $M \& E$ is necessary to your stakeholders, it is important that you consider their information needs, as well as your own. You will therefore need to identify the key internal stakeholders and decide on how to include them in the design, implementation, analysis and communication of findings. Examples of people you might want to involve are (a) Deans of faculties (b) Heads of Departments (c) Unit coordinators, students and other University Administrators.

Step 5: Decide the key issues and questions you would want to examine

The next important step is to find out the issues and questions you would like to observe. Such issues may include how regular does Lecturer attend lectures, relationship between lecturer and students, mode of presentation which has to do with methodologies applied in teaching social studies, feedback from students, type of teaching materials used, lecture room climate among others.

Step 6: Clarifying your aims, objectives, activities and pathways to change

In order to assess progress, you need to know what you are trying to achieve and how: that is, your aims, objectives and planned activities. It is helpful to start by clarifying your aims and objectives (i.e. your desired impacts and outcomes) and then plan the activities that you (and other actors) will carry out to achieve them.

Step 7: Indicate the information (indicators) you want to collect

In this stage you will need to identify the information you will need to collect by developing the indicators. Indicators are specific and concrete pieces of information which will help you record the changes you are trying to achieve. It is strategic to locate and track useful 'outcome' and 'impact' indicators. An example of an outcome indicator might be high performance of students in external examinations, teacher commitment and dedication to duty. It is imperative that indicators are relevant, specific and are accompanied by open ended questions which include questions that find out why and how changes occur and what they mean to students. This is very necessary because it helps to explore unintended changes, understand the reasons for change and interpret changes.

Step 8: Decide how to collect the information

Collection of information can be conducted through internal monitoring or external evaluation. It is better to collect information from a range of internal and external sources. It should be noted that for each indicator (such as relevance, effectiveness or impacts) you will require to work out how to collect the date. In collecting data, you will consider the issue and indicator, information collection method and frequency (whether it will be annually or quarterly) including baseline.

Step 9: Assesse your contribution/influence

The M\&E of teaching and learning of social studies may show positive outcomes and impacts associated with your supervision and mode of teaching but this may also be attributed to other factors or actors (individuals or organisations) 
rather than your supervision and methodology. Therefore, an important aspect of M\&E for teaching and learning of social studies should include assessing the influence or contribution your supervision and teachers activities have made to any observed outcomes or impacts in students' performance.

Step 10: Analyse and use the information

Information acquired from M\& E activities can only be useful if they are analysed and put to good use. The main aim of monitoring and evaluation is to facilitate internal decision making and planning, it therefore beholds on M\&E team to occasionally analyse, assess, and actually use the information collected to improve teaching and learning of social studies. When you have analysed the data you could hold internal meetings occasionally with lecturers or organise a specific monitoring and evaluation workshop to share, discuss and interpret findings. You should use the data to answer major questions concerning teacher and student performance. It is pertinent to note that if you did not put in use the findings/information collected from the activities, the whole exercise is a waste.

Step 11: Communicating the data

This stage has to do with dissemination of the result of the monitoring and evaluation of social studies teaching and learning processes. It is very necessary to communicate the data or result to important stakeholders such as students, lecturers, Deans of Faculties, Heads of Departments, Coordinators of Units and Principal Officers of the Institution. The information could also be incorporated into Annual reports or provide a useful background document to give people who want to know what the monitoring and evaluation of teaching and learning of social studies is set to achieve and actually achieved.

\section{Conclusion}

This paper examined monitoring and evaluation of teaching and learning of social studies in institutions of higher learning. It reviewed different definitions of monitoring and evaluation by various authors and looked at the importance of monitoring and evaluation of teaching and learning of social studies which include, to provide accountability, tracking of programme implementation, improving programme and showing whether the programme is meeting its objectives among others. The key components of monitoring and evaluation were discussed, they include inputs, processes, outputs, outcomes and impact. The paper provided the overview of the benefits of monitoring and evaluation of teaching and learning of social studies and the consequences of failure to monitor and evaluate teaching and learning of social studies in higher institutions in Nigeria which include poor attitude to work, sexual harassment, sorting, intimidation among others. The paper therefore concludes that internal monitoring and evaluation team be established in higher institutions, to ensure adequate monitoring and evaluation of teaching and learning of social studies in institutions of higher learning for effective implementation of social studies contents. That the team to anchor monitoring and evaluation of social studies teaching and learning processes should include key stakeholders such as Deans, Heads of Departments, Unit Coordinators and students. That reports of the M\&E should be disseminated to assure stakeholders that teaching and learning of social studies is achieving what it is set out to achieve and this may in turn help other institutions improve quality of teaching and subsequently the quality of their graduates.

\section{Recommendations}

Based on the findings, the following recommendations were made:

An internal monitoring and evaluation team be set up in institutions of higher learning, to monitor teaching and learning of social studies to ensure quality learning.

Team members to include, Deans of faculties, Head of Departments, Professors, Unit Coordinators and Students who are experienced on the skills required of lecturers

Team members to identify the indicators (that is what team members will look out for when they embark on monitoring) that will guide the exercise.

Team members should adhere to the criteria of selecting indicators for monitoring and evaluation so that the rightful indicators which will check the gaps to be filled are identified.

The team should endeavour to make positive use of information gathered from monitoring and evaluation to improve teaching and learning of social studies.

\section{References}

Arnott, D. G. (2014). Factors affecting the implementation of elementary science curriculum in three Northern Saskatchewan Provincial schools. University of Saskatchewan Thesis. Unpublished. Retrieved from https://ecommons.usask.co/bitstream/handle/10388/etd

Chukwu, C. L., \& Taiwo, L. (2016). Violence in Nigerian universities: swot analysis a tool for strategic way forward. In 
Insecurity and Education in Nigeria, 289 - 307.

Chukwu, L. C. (2015). Emerging trends for quality performance in schools: a hand book for educators and administrators. Nigeria: Daily Graphics Nigeria Limited

Disha, M. (2017). Evaluation in teaching and learning process/education. Retrieved from www.yourarticlelibrary.com/static-2/evaluation-in-teachingandlearning-process-education/92476/

Education Innovation Fund, Oxford University (2014). A step by step guide to monitoring and evaluation. Retrieved from http://www.geog.ox.ac.uk/research/technologies/projects/monitoringandevaluation

FME and FIS. (2010). Education quality assurance handbook in Nigeria (Revised edition). Abuja: Federal Ministry of Education

Food and Agriculture Organization of the United Nations (2017). Monitoring and evaluationfor learning and performance improvement. Retrieved from www.fao.org/investment-learning-platform

Goyal, R., Pittman, A., \& Workman, A. (2010). Measuring change: monitoring and evaluating leadership programmes, a guide for organisations. Retrieved from www.learningpartnership.org/docs/pubs/monitoringandevaluation.html

Harvey, V. S., \& Struzziere, J. A. (2008). Professional development and supervision of school psychologists from intent to expert ( $2^{\text {nd }}$ edition). California: Corwin Press.

Health Mandatory Policy Directive (2005). Guidelines for developing monitoring and evaluation plans for humanResources for health. Retrieved from https://www.capacityplus.org/files/resources/guideline

Hobson, K., Mayne, R., \& Hamilton, J. (2013). Step by step guide to monitoring and evaluation. Retrieved from http://www.geog.ox.ac.uk/research/technologies/projects/monitoringandevaluation

https//www.unscn.org (2017). Monitoring and evaluation. Retrieved from https//www.unscn.org/wcb/session-24-monitoring-and-evaluation

Mwagi, J. K., Nyang'wara, B. M., \& Kulet. (2015). Factors affecting the effectiveness of monitoring and evaluation of constituency development fund projects in Kenya: a case study of Laikipia West constituency. In Journal of Economics and Finance, 6(1), Ver 1. Retrieved from www.iosrjournals.org

Myers, J. (2017). Assessment and evaluation in Social studies classrooms. Retrieved from http://www.learnalberta.ca/contentssass/html/pdf

OECD. (2017). Learning our lesson: review of quality teaching in higher education. Retrieved from https://www.oecd.org/edu/imhe/44058352.pdf

\section{Copyrights}

Copyright for this article is retained by the author(s), with first publication rights granted to the journal.

This is an open-access article distributed under the terms and conditions of the Creative Commons Attribution license (http://creativecommons.org/licenses/by/4.0/). 